\title{
Growth rate responses to magnesium or sodium supplements in lambs grazing dual-purpose wheats*
}

\author{
H. Dove ${ }^{1,3}$, G. McMullen ${ }^{2}$ and W.M. Kelman ${ }^{1}$
}

\author{
${ }^{1}$ CSIRO Plant Industry \\ GPO Box 1600, Canberra, ACT 2601, Australia \\ ${ }^{2}$ Agricultural Research Institute, New South Wales Department of Primary Industries \\ Pine Gully Rd, Wagga Wagga, NSW 2650, Australia
}

\begin{abstract}
Lambs grazed vegetative wheat crops in south-east Australia with and without $\mathrm{Mg}$ or $\mathrm{Na}$ supplements. Relative to the requirements for lamb growth, wheat forage was marginal for $\mathrm{Mg}$, adequate for $\mathrm{Ca}$, excessive for $\mathrm{K}$ and very low in $\mathrm{Na}$. In Experiment 1 , a combined $\mathrm{Mg} / \mathrm{Ca} / \mathrm{Na}$ supplement led to a $54 \%$ increase in lamb liveweight gain compared with unsupplemented lambs. Further experiments were then conducted to separate the responses to $\mathrm{Mg}$ or $\mathrm{Na}$. In Experiment 2, $\mathrm{Mg}$ or Na supplements increased liveweight gain by 24 and 37\%, respectively. In Experiment 3, $\mathrm{Mg}$ intake by lambs was increased by fertilizing the wheat crop with $\mathrm{MgSO}_{4}$. This increased wheat forage $\mathrm{Mg}$ from below $(0.10 \% \mathrm{DM})$ to above $(0.17 \% \mathrm{DM})$ that required by lambs and resulted in $24 \%$ faster liveweight gain at a stocking rate of 18/ha. At higher stocking rates $(33,47 \mathrm{sheep} / \mathrm{ha})$, the response to $\mathrm{Mg}$ declined as herbage supply became increasingly limited. In the final experiment, Na-supplemented lambs grew $25 \%$ faster than unsupplemented lambs. The observed responses to $\mathrm{Mg}$ and $\mathrm{Na}$ may be separate responses, but diets low in $\mathrm{Na}$ and high in $\mathrm{K}$ have been shown to impair ruminal Mg absorption. The wheat forage in Experiments 1-4 contained 3-4\% of DM as $\mathrm{K}$ and very low $\mathrm{Na}$ concentrations. We present evidence suggesting that the response to Na could partly be due to improved $\mathrm{Mg}$ absorption, arising from a reduction in dietary $\mathrm{K}: \mathrm{Na}$ ratio.
\end{abstract}

KEY WORDS: winter wheat, potassium, sodium, calcium, magnesium, liveweight gains, sheep

\section{INTRODUCTION}

The grazing of long-season, dual-purpose wheats by lambs can result in rapid liveweight gains (e.g., 320-360 g/day) but there can also be marked variability in daily gains (140-360 g/day) in animals grazing seemingly similar crops (Dove,

\footnotetext{
* Supported by the Grains Research and Development Corporation and the Grain \& Graze Project

${ }^{3}$ Corresponding author: e-mail: Hugh.Dove@csiro.au
} 
2006). This can partly be related to lamb genotype, with Merino lambs usually having lower rates of gain (140-240 g/day), but even when re-expressed as a percentage of liveweight, there is still a 2-fold range in gains of lambs grazing dual-purpose wheat $(0.5-1.0 \%$ of liveweight; Dove, 2006). The nutritive value of winter wheat forage is very high (OM digestibilities 75-90\%; crude protein contents $22-26 \% \mathrm{DM}$ ) and estimated forage intakes are sufficient for high rates of gain (Dove, 2006). We therefore investigated whether wheat forage, when grown under southern Australian conditions, is deficient in any minerals that would limit or cause variability in liveweight gain of grazing lambs.

Berger (1992) reported that low Mg levels in winter wheat could limit livestock growth. In south-eastern Australia, wheat forage can also be low in $\mathrm{Mg}$ due to reduced plant $\mathrm{Mg}$ absorption when the crop grows in low $\mathrm{pH}$ soils with high K content (Coventry et al., 1987; Dove, 2007). In 4 wheat-grazing trials, we therefore investigated weight gain responses to $\mathrm{Mg}$ supplementation of young sheep. Responses to Na supplementation were also studied, because survey data indicate that wheat forage can be very deficient in $\mathrm{Na}$ (Dove, 2007).

\section{MATERIAL AND METHODS}

\section{Experiments 1 and 2}

In Experiment 1, liveweight gain was measured over a 28-day grazing period (11 July-8 August) in crossbred lambs (mean initial weight $37 \mathrm{~kg}$ ) grazing 6 plots of winter wheat (Triticum aestivum cv. Wedgetail) at a stocking rate of 35 lambs/ha. In 3 of the plots, lambs received no supplement, whilst in the other 3 plots, lambs received a supplement of 2:2:1 magnesium oxide $(\mathrm{MgO})$ :limestone $\left(\mathrm{CaCO}_{3}\right)$ :salt $(\mathrm{NaCl})$ at the rate of $20 \mathrm{~g} / \mathrm{lamb}$ per day. The salt was required to ensure that the supplement was consumed. Wheat forage availability over the grazing period was such that herbage intake was not limited.

In Experiment 2, separate $\mathrm{Mg}$ and $\mathrm{Na}$ supplements were used, to distinguish between responses to $\mathrm{Mg}$ or $\mathrm{Na}$, which were confounded in Experiment 1 . Liveweight gain was measured over 29 days in late winter in crossbred lambs (mean initial weight $37 \mathrm{~kg}$ ) grazing Wedgetail wheat at 20/ha. The trial involved 3 treatments: no supplement, a $\mathrm{Na}$ supplement $(\mathrm{NaCl}$ at the rate of $4 \mathrm{~g}$ /sheep per day) and a $\mathrm{Mg}$ supplement ( $\mathrm{MgO}$ at the rate of $17 \mathrm{~g} /$ sheep per day). Due to the low palatability of $\mathrm{MgO}$, it was fed together with a small quantity (approximately $80 \mathrm{~g} /$ sheep per day) of poor-quality roughage (DMD $<50 \%$ ). By contrast with Experiment 1, the trial was conducted under drought conditions and available herbage restricted intake and thus liveweight gain over the period. 


\section{Experiment 3}

Merino lambs (mean initial weight $30 \mathrm{~kg}$ ) grazed winter wheat (cv. Mackellar) at 18,33 or 47 lambs/ha between 14 August and 15 September, 2006. They either remained unsupplemented or were 'supplemented' indirectly with $\mathrm{Mg}$ by fertilizing some plots with $\mathrm{MgSO}_{4}$ (425 kg/ha), 3 weeks before grazing commenced, to increase forage $\mathrm{Mg}$ concentrations. Liveweight gains were estimated from initial and final fasted liveweights.

\section{Experiment 4}

Merino lambs from the same group as Experiment 3 grazed at 36/ha on 2 replicates in a separate area of the same crop used in Experiment 3, but which had not received Mg fertilizer. From 14 August-15 September, 2006, these lambs were either unsupplemented or had ad libitum access to $\mathrm{Na}$ fed as loose salt in shallow troughs. Fasted liveweight gain was determined as in Experiment 3.

\section{Chemical and statistical analyses}

Samples of wheat forage from all 4 experiments were assayed for their OM digestibility and crude protein content using standard procedures. In addition, concentrations of the major minerals were determined in all 4 experiments by $\mathrm{X}$ ray fluorescence (Norrish and Hutton, 1977).

All 4 experiments were conducted as replicated randomized blocks and responses were evaluated using analysis of variance for this design.

\section{RESULTS}

The OM digestibility of all grazed crops was in the range $75-90 \%$; crude protein was in the range $22-26 \%$ of DM. The nutritive value of the forage was thus very high and would not have limited liveweight gain. The concentration of selected major minerals in the forage DM is shown in Table 1, together with the requirements for growth in young sheep (SCA, 1990). Relative to the sheep requirements for growth, all wheat forages were marginal for $\mathrm{Mg}$ except the fertilized crop in Experiment 3, in which the application of $\mathrm{MgSO}_{4}$ fertilizer increased forage $\mathrm{Mg}$ content above animal requirements. The Ca content of the crops was close to or exceeded animal requirements. By contrast, the crops contained 6-7 times the amount of $\mathrm{K}$ required by animals. With the exception of the forage in Experiment 1, which contained $\mathrm{Na}$ at the level required by animals, the other crops were markedly deficient in $\mathrm{Na}$. No systematic difference in mineral content was observed between the two wheat cultivars used in this work. 
Table 1. Mineral concentrations in wheat forage (Experiments 1-4) in relation to requirements for growth in young sheep

\begin{tabular}{|c|c|c|c|c|}
\hline \multirow{2}{*}{ Item } & \multicolumn{4}{|c|}{ Mineral, \% DM } \\
\hline & $\mathrm{Mg}$ & $\mathrm{Ca}$ & $\mathrm{K}$ & $\mathrm{Na}$ \\
\hline Requirement for growth & 0.12 & 0.15 & 0.50 & 0.05 \\
\hline \multicolumn{5}{|l|}{ Forage content } \\
\hline range, Experiments 1-4 & $0.10-0.17$ & $0.15-0.30$ & $2.96-3.50$ & $0.005-0.05$ \\
\hline experiment 3: unfertilized & 0.10 & 0.20 & 3.50 & 0.005 \\
\hline fertilized & 0.17 & 0.23 & 3.27 & 0.008 \\
\hline
\end{tabular}

In Experiment 1, supplemented animals grew significantly faster $(54 \% ; \mathrm{P}<0.05)$ than their unsupplemented cohorts (Table 2). Since the forage contained adequate $\mathrm{Ca}$ for growth and $\mathrm{Na}$ content was equal to sheep requirements, the response was attributed to $\mathrm{Mg}$. However, the possible confounding effect of the $\mathrm{Na}$ was the reason for separate supplementation with $\mathrm{Na}$ and $\mathrm{Mg}$ in Experiment 2. In this case, there were significant responses to both $\mathrm{Na}$ and $\mathrm{Mg}$ supplements $(\mathrm{P}<0.05)$. Sheep given the Na supplement grew 37\% faster than unsupplemented sheep, whilst the equivalent figure for sheep given the Mg supplement was $24 \%$.

Table 2. Liveweight gains of supplemented or unsupplemented lambs grazing Wedgetail wheat forage

\begin{tabular}{llc}
\hline Item & Liveweight gain, g/day \\
\hline Experiment 1: & unsupplemented & 184 \\
& Mg-supplemented $^{1}$ & 283 \\
Experiment 22: unsupplemented & 131 \\
& Na-supplemented & 179 \\
& Mg-supplemented & 162 \\
\hline
\end{tabular}

${ }^{1}$ supplement consisted of 2:2:1 mixture of $\mathrm{MgO}_{\mathrm{CaSO}}{ }_{4}: \mathrm{NaCl}$ in Experiment 1. In Experiment 2, $\mathrm{Na}$ was provided as $\mathrm{NaCl}$ and $\mathrm{Mg}$ as $\mathrm{MgO}$

${ }^{2}$ lower liveweight gains in this study reflect drought conditions

In Experiment 3, there was a marked response of wheat forage $\mathrm{Mg}$ concentration to the application of $\mathrm{Mg}$ fertilizer. In the unfertilized crop, forage $\mathrm{Mg}$ concentration was always lower $(0.09-0.11 \% \mathrm{DM})$ than the level required for growth in young sheep $(0.12 \% \mathrm{DM})$. Application of $\mathrm{Mg}$ fertilizer raised this concentration significantly $(\mathrm{P}<0.05)$, to as high as $0.26 \% \mathrm{DM}$ in the week following application; for the actual grazing period (days 19-51 after application), forage $\mathrm{Mg}$ concentration in fertilized plots averaged $0.17 \%$ DM. There was a marked interaction between stocking rate and fertilizer application on lamb liveweight gain $(\mathrm{P}<0.01)$. On the unfertilized forage, sheep grazing at 18,33 and $47 /$ ha grew at 148,162 and $164 \mathrm{~g} /$ day; the main effect of stocking rate was not significant. 
On Mg-fertilized wheat, the equivalent gains were 185, 169 and $138 \mathrm{~g} /$ day. The liveweight gain responses to $\mathrm{Mg}$ fertilizer were thus 25,4 and $-16 \%$, respectively, at these 3 stocking rates. The progressive reductions in response can be related to herbage supply, which declined more rapidly $(\mathrm{P}<0.01)$ to low levels in sheep grazing at the higher stocking rates.

In Experiment 4, lambs offered salt consumed, on average, $30 \mathrm{~g} /$ day, equivalent to about $12 \mathrm{~g} \mathrm{Na} /$ day, and grew at $211 \mathrm{~g} /$ day, $25 \%$ faster than unsupplemented lambs (169 g/day; $\mathrm{P}<0.05)$.

\section{DISCUSSION}

In the United States, Mg supplements have reduced the incidence of grass tetany in cattle grazing winter wheats. Wheat forage is often also deficient in $\mathrm{Na}$ and responses to Na supplements have also been noted (Berger, 1992). Our data extend such findings by demonstrating liveweight responses in lambs showing no symptoms of clinical Mg deficiency. Marked responses to Na supplementation were also observed. Given the very low Na content of most of the wheat forages in the present study, this may represent a true Na response. For example, the consumption of $30 \mathrm{~g}$ salt/day (Experiment 4) would raise the effective dietary concentration of $\mathrm{Na}$ well above the daily $\mathrm{Na}$ requirement for lamb growth. However, there are also sound reasons for expecting a range of minerals, especially $\mathrm{Mg}, \mathrm{K}$ and $\mathrm{Na}$ to influence the $\mathrm{Mg}$ content of plant tissue (Coventry et al., 1987) and the ruminal absorption of Mg by livestock (Martens et al., 1987; Berger, 1992).

In south-east Australia, wheat is often grown in areas with topsoils of low $\mathrm{pH}$ and high $\mathrm{K}$ content (Coventry et al., 1987). These soil conditions reduce $\mathrm{Mg}$ uptake by plants (Coventry et al., 1987) and also lead to high K concentrations in plant tissue. This is the likely explanation of the high $\mathrm{K}$ and low $\mathrm{Mg}$ in our forages. Forage Ca contents in Experiments 1-4 were typical of wheats grown in south-eastern Australia, and were usually at or slightly above lamb growth requirements (Table 1). Forage $\mathrm{Mg}$ content was positively but poorly related to forage $\mathrm{Ca}$ content $\left(\mathrm{r}^{2}=0.171\right)$. The high $\mathrm{K}$ and low $\mathrm{Na}$ concentrations in the wheat forage are a cause for concern, because high $\mathrm{K}$ and low $\mathrm{Na}$ intakes result in a high $\mathrm{K}: \mathrm{Na}$ ratio in rumen fluid, which in turn greatly reduces $\mathrm{Mg}$ absorption from the rumen (Martens et al., 1987; SCA, 1990; Berger, 1992). Although high forage $\mathrm{K}$ can often also reduce forage Na content (see SCA, 1990), there was no relationship between forage $\mathrm{K}$ and forage $\mathrm{Na}$ in Experiments 1-4. Martens et al. (1987) reported a 55\% increase in $\mathrm{Mg}$ absorption when sheep consuming a low-Na diet were supplemented with $\mathrm{Na}$ into the rumen. It follows that in sheep consuming high-K forage, supplementation with $\mathrm{Na}$ could lower rumen $\mathrm{K}: \mathrm{Na}$ ratio and increase $\mathrm{Mg}$ absorption. Our observed responses to $\mathrm{Na}$ could thus be 
due, at least in part, to an improvement in the $\mathrm{Mg}$ status of the animals. This aspect requires further investigation under field conditions in Australia.

In order to prevent grass tetany in beef cattle grazing winter wheat, Berger (1992) recommended that animals be supplemented with a 1:1 mix of $\mathrm{NaCl}: \mathrm{MgO}$. For lambs grazing wheat forage under Australian grazing conditions, our results suggest that a similar supplementation policy would be sensible. Given the cost of the supplements used in the present study (about 1 cent/sheep per day) and the value of the resultant extra liveweight gain (about A $\$ 1.60 / \mathrm{kg}$ ), it would also be economically worthwhile.

\section{REFERENCES}

Berger L.L., 1992. Grass Tetany: Causes and Prevention. Salt Institute Report. (New version accessed Jan. 2007 at http://www.saltinstitute.org/tetany.html)

Coventry D.R., Morrison G.R., Reeves T.G., Hirth J.R., Fung K.K.H., 1987. Mineral composition and responses to fertiliser of wheat grown on a limed and deep ripped soil in north-eastern Victoria. Aust. J. Exp. Agr. 27, 687-694

Dove H., 2006. Grazing dual-purpose wheats for liveweight gain. Technical Update, Grains Research and Development Corporation. Wagga, NSW, pp. 193-198

Dove H., 2007. Mineral nutrition of sheep grazing dual-purpose wheats. Technical Update, Grains Research and Development Corporation. Wagga, NSW, pp. 71-75

Martens H., Kubel O.W., Gabel G., Honig H., 1987. Effects of low sodium intake on magnesium metabolism of sheep. J. Agr. Sci. 108, 237-243

Norrish K., Hutton J.T., 1977. Plant analyses by X-ray spectrometry. I - Low atomic number elements, sodium to calcium. X-Ray Spectrom. 6, 6-11

SCA, 1990. Feeding Standards for Australian Livestock: Ruminants. Standing Committee for Agriculture and CSIRO. Melbourne, pp. 266 